\title{
Introducing a new limit states design concept to railway concrete sleepers: an Australian experience
}

\author{
Sakdirat Kaewunruen ${ }^{1}$, Alex M. Remennikov ${ }^{2}$ and Martin H. Murray ${ }^{3}$ \\ ${ }^{1}$ RailCorp - Track Engineering, Sydney, NSW, Australia \\ ${ }^{2}$ School of Civil, Mining and Environmental Engineering, University of Wollongong, Wollongong, NSW, Australia \\ ${ }^{3}$ Science and Engineering Faculty, Queensland University of Technology, Brisbane, QLD, Australia \\ *Correspondence: sakdirat@hotmail.com \\ Edited by: \\ Oliver Hayden, Siemens AG, Germany \\ Reviewed by: \\ Julia Irene Real Herráiz, Polytechnic University of Valencia, Spain \\ Akira Aikawa, Railway Technical Research Institute, Japan
}

Keywords: railway/railroad, concrete sleepers or crosstie, limit states design, dynamic properties, damping, cost and environmental benefits, risk and reliability, infrastructure and asset management

Over 50 years, a large number of research and development projects with respect to the use of cementitious and concrete materials for manufacturing railway sleepers have been significantly progressed in Australia, Europe, and Japan (Wang, 1996; Murray and Cai, 1998; Wakui and Okuda, 1999; Esveld, 2001; Freudenstein and Haban, 2006; Remennikov and Kaewunruen, 2008). Traditional sleeper materials are timber, steel, and concrete. Cost-efficiency, superior durability, and improved track stability are the main factors toward significant adoption of concrete materials for railway sleepers. The sleepers in a track system, as shown in Figure 1, are subjected to harsh and aggressive external forces and natural environments across a distance. Many systemic problems and technical issues associated with concrete sleepers have been tackled over decades. These include pre-mature failures of sleepers, concrete cancer or ettringite, abrasion of railseats and soffits, impact damages by rail machinery, bond-slip damage, longitudinal and lateral instability of track system, dimensional instability of sleepers, nuisance noise and vibration, and so on (Pfeil, 1997; Gustavson, 2002; Kaewunruen and Remennikov, 2008a,b, 2013). These issues are, however, becoming an emerging risk for many countries (in North and South Americas, Asia, and the Middle East) that have recently installed large volumes of concrete sleepers in their railway networks (Federal Railroad Administration, 2013). As a result, it is vital to researchers and practitioners to critically review and learn from previous experience and lessons around the world.

Although those problems have been resolved through a systemic approach, there has been a significant demand to optimize the use of materials and to reduce wastes in concrete sleeper production. In doing so, there have been two research trends: materials and design improvement. The outcomes from both research directions must enhance and comply with the systemic performance and specific criteria as well as the operational environments of such railway networks. Often engineering specifications by rail authorities are in place to mitigate and monitor imminent risks that could potentially interconnect with other elements. Because of the systemic complexities, the potential of many material-driven researches becomes limited and relates to only traditional materials. For example, composite materials were developed purposely to equate just timber characteristics. Also, a recycled polymer material was tested as a timber-replacement alternative (Manalo et al., 2010).

Breaking through the systemic complexities, a research outcome has led to an introduction of limit states design concept to concrete sleepers in Australia (Remennikov et al., 2012). The change in design concept (which is about 5-6 years behind the European counterpart) empowers the leaner and greener potential for manufacturing sleepers: either by reducing material wastes or by embracing new material innovation. The contemporary design philosophy for railway concrete sleepers is based on the "allowable stress principle" taking into account only the quasi-static wheel loads, which results in overly conservative, deficient design for concrete sleepers. The permissible stress design concept has fundamentally dominated in current Australian and some international design standards for concrete sleepers (i.e. in North America and Asia). Field data have also raised concerns about the permissible stresses design technique for concrete sleepers, which considerably relies on material strength reductions and then leads to over-designing concrete sleepers. It is well known that the permissible stress design method does not consider the ultimate strength of materials, probabilities of actual loads, and risks associated with failures and other operational and maintenance factors.

Empirical data collected by railway organizations report that railway tracks, especially railway concrete sleepers, might have untapped capacity that could bring potential economic advantage to infrastructure owners (Kaewunruen and Remennikov, 2009a,b). The research project to study the actual load carrying capacity of concrete sleepers was developed as a collaborative project between several Australian universities and the industry partners within the framework of the Australian Cooperative Research Center for Railway Engineering and Technologies (RailCRC). The research tasks were required to perform fundamental studies of the loading conditions, the static 


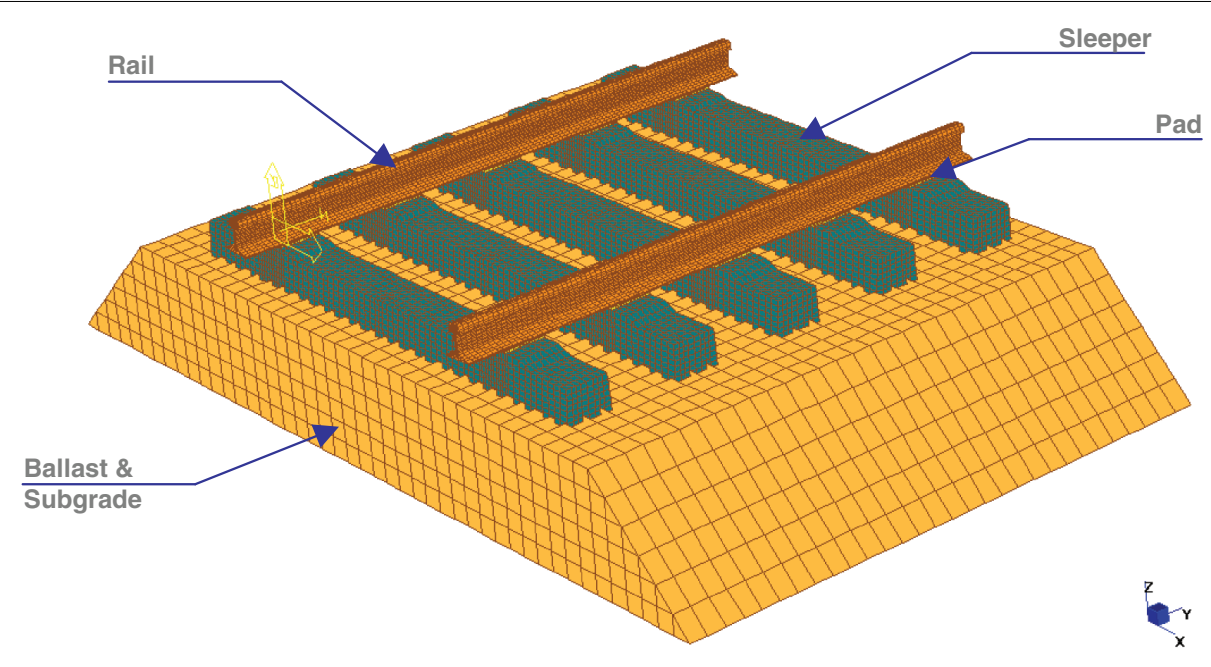

FIGURE 1 |Typical components of railway tracks.

behavior, the dynamic response, and the impact resistance of the concrete sleepers. The research outcome was the development of the design guideline and conversion for concrete sleepers into a more rational limit states design format, accounting for the statistical nature, probability, and realistic risk of failure. Limit states design concept, which considers the probabilistic dynamic loading condition, is regarded as a more logical entity for the development of a new design approach for concrete sleepers.

An early lesson railway owners learnt was that concrete sleepers behaved under a variety of unexpected dynamic load conditions and at times could be described as "buoyant," bouncing in many ways depending on train speed, curve, rail joints, and train wheel and ballast conditions. It was therefore evident that sleeper weight was a key factor to stabilize dynamic behavior of railway tracks in addition to track decay rate and damping characteristics of materials. As a result, the number of pre-stressed tendons, their position, and their level of pre-stress were the least of design factors in terms of cost minimization. In UK, it was found that the principle contributors to cost are the sleeper weight, handle-ability, and installation techniques (Kaewunruen et al., 2011a,b; Smith, 2012). It was also noted that early cracking failures (which were very early) around the railseats were over considerable lengths of track and were due to excessive wheel flats. Recognition of that possibility or correlation to dynamic load actions has been made over the time. It has later been found that the major cause of cracking is the infrequent but highmagnitude wheel loads produced by the small percentage of irregular wheels or railhead surface defects; both these are crudely accounted for in the allowable stress design method by an over-conservative single load factor (Kaewunruen, 2007). Also such a wheel flat, while a one-off for one train and for any one particular sleeper, is in fact disastrous for miles of track as the train proceeds to demolish the next sleeper. On this ground, there have been some further performance-based criteria, additional to fundamental engineering and fatigue properties, in adopting a new design or a new material, including dynamic behavior of railway track and sleepers, early cracks of sleepers due to impact forces, and cost savings. With these criteria altogether with systemic risks, many researches into new materials failed to comply (Kaewunruen, 2013).

In order to introduce the limit states design concept for railway sleepers in Australia, there have been a number of investigations into impact load action history, dynamic properties of railway track and its components, test programs, and structural capacity results as well as the strategic recommendations for track capacity upgrade for existing and new concrete-sleepered tracks (Kaewunruen and Remennikov, 2010). The test programs have considered static, dynamic, impact, and low-cycle fatigue behavior of concrete sleepers. These test programs were developed based on railtrack load history records over years. Numerical studies had also been carried out to confirm the test results. A trial to increase the maximum axle load has been carried out in a heavy haul rail network in Australia. Its performance will soon be investigated in accordance with our current research at the University of Wollongong, which is focused on the life cycle and remaining life prediction of aged concrete sleepers (Kaewunruen and Remennikov, 2014). By all means, it should be noted that track structures of any rail authorities vary significantly and their ability to exploit existing tracks should be reviewed on a case by case basis. Each track component shall be re-evaluated altogether as a systematic point of view.

The new limit states concept permits a sleeper design with a reduced depth and weight that is beneficial to any lowclearance railway corridor. In addition to cost saving, the use of the new design method has a positive, potential gearing to environment and sustainability in a railway corridor over its life cycle. Amounts and mixture of cement and cementreplacement materials (i.e. fly ash, furnace slag, polymeric fiber, etc.) can then be innovated to improve material damping and strength. We have found that, based on the cost of materials, the potential cost saving of $15 \%$ can be made by adopting the limit states principle (Remennikov 
et al., 2012). Note that the project cost during track possessions is excluded because such track possession costs are significantly dependent on construction type, location, local population, replacement transport services, track access, contingency plan, and so on. For example, bus services arranged to replace trains during the construction could potentially cost over 10 times of the construction material cost in a smallscale project. It will be unfair to use the whole project cost to justify a component cost. However, such material cost savings are now very real: recently, application of limit states was able to reduce by $20 \%$ the amount of concrete used in sleepers in a new Australian heavy haul railway line located in Western Australia. Saving \$3-\$5 per sleeper might be small but the profit can simply increase with economy of scale, especially when approximately one million of sleepers are generally required to build just 500-700 km long of a single railway track. Furthermore, on the basis of the limit states principle, it is highly likely that existing concrete sleepers are potential to cater faster and heavier trains. This is priceless! Importantly, we need to remember that cost saving is just a financial benefit; reducing carbon footprint (from cement production and material wastes) of railway construction is a legacy.

\section{ACKNOWLEDGMENTS}

The authors are grateful to the Australian CRC for Railway Engineering and Technologies (Rail-CRC) for the financial support throughout this study. The first author wishes to thank the Australian Government Department of Innovation, Education, and Research for Endeavor Executive Award, which financially supported his fellowships at Massachusetts Institute of Technology's Department of Civil and Environmental Engineering; Harvard University's John F. Kennedy School of Government; and Chalmers University of Technology's Center for Railway Mechanics.

\section{REFERENCES}

Esveld, C. (2001). Modern Railway Track. Netherlands: MRT Press.

Federal Railroad Administration. (2013). International Concrete Crosstie and Fastening System Survey. Washington DC: US Department of Transportation.

Freudenstein, S., and Haban, F. (2006). Development and testing of heavy haul sleepers. Int. Railway J. 46, 32-33.

Gustavson, R. (2002). Structural Behaviour of Concrete Railway Sleepers. Ph.D. thesis, Department of Structural Engineering, Chalmers University of Technology, Göteborg.

Kaewunruen, S. (2007). Experimental and Numerical Studies to Evaluate the Dynamic Behaviour of Prestressed Concrete Sleepers Under Severe Impact Loading. Ph.D. thesis, School of Civil, Mining, and Environmental Engineering, University of Wollongong, Wollongong, NSW.

Kaewunruen, S. (2013). Performance Review of CarbonLoc Material for Alternative Turnout Bearers. Technical Report No. TR211. Track Services RailCorp, 17. Sydney.

Kaewunruen, S., and Remennikov, A. M. (2008a). "Trends in vibration-based structural health monitoring of railway sleepers," in Mechanical Vibration: Measurement, Effect, and Control, ed. R. C. Sapri (New York, NY: Nova Science Publishers), 3-4.

Kaewunruen, S., and Remennikov, A. M. (2008b). Dynamic effect of vibration signatures of cracks in railway prestressed concrete sleepers. Adv. Mat. Res. 41-42, 233-239. doi:10.4028/www.scientific. net/AMR.41-42.233

Kaewunruen, S., and Remennikov, A. M. (2009a). Structural safety of railway prestressed concrete sleepers. Aust. J. Struct. Eng. 9, 129-140.

Kaewunruen, S., and Remennikov, A. M. (2009b). Impact fatigue responses of railway prestressed concrete sleepers. IES J. A Civ. Struct. Eng. 2, 47-58. doi:10.1080/19373260802479377

Kaewunruen, S., and Remennikov, A. M. (2010). Dynamic crack propagations of prestressed concrete sleepers in railway track systems subjected to severe impact loads. ASCE J. Struct. Eng. 136, 749-754. doi:10.1061/(ASCE)ST.1943-541X. 0000152

Kaewunruen, S., and Remennikov, A. M. (2013). On the residual energy toughness of prestressed concrete sleepers in railway track structures subjected to repeated impact loads. Electron. J. Struct. Eng. 13, 41-61.

Kaewunruen, S., and Remennikov, A. M. (2014). Experimental load rating of aged railway concrete sleepers. Eng. Struct. doi:10.1016/j.engstruct.2014. 06.032

Kaewunruen, S., Remennikov, A. M., and Murray, M. H. (2011a). Greener \& leaner: unleashing the capacity of railroad concrete ties. ASCE J. Transp. Eng.
137, 241-247. doi:10.1061/(ASCE)TE.1943-5436. 0000215

Kaewunruen, S., Remennikov, A. M., and Murray, M. H. (2011b). Limit states design of concrete sleepers. Proc. ICE Transp. 165, 81-85. doi:10.1680/tran.9. 00050

Manalo, A., Aravinthan, T., Karunasena, W., and Ticoalu, A. (2010). A review of alternative materials for replacing existing timber sleepers. Compos. Struct. 92, 603-611. doi:10.1016/j.compstruct. 2009.08.046

Murray, M. H., and Cai, Z. (1998). Literature Review on the Design of Railway Prestressed Concrete Sleeper. RSTA Research Report. Brisbane: Engineers Australia.

Pfeil, H. (1997). Rail Seat Abrasion in Concrete Sleepered Track. Technical Report No. TR-016. Sydney, NSW: RSA Technical Services, RailCorp, 35.

Remennikov, A. M., and Kaewunruen, S. (2008). A review on loading conditions for railway track structures due to train and track vertical interaction. Struct. Control Health Monit. 15, 207-234. doi:10.1002/stc. 227

Remennikov, A. M., Murray, M. H., and Kaewunruen, S. (2012). Reliability based conversion of a structural design code for prestressed concrete sleepers. Proc. IMechE F J. Rail Rapid Transit. 226, 155-173. doi:10.1177/0954409711418754

Smith, T. J. (2012). Discussion of limit states design of railway concrete sleepers. ICE Transp. 165.

Wakui, H., and Okuda, H. (1999). A study on limitstate design for prestressed concrete sleepers. Concrete Libr. JSCE 33, 1-25.

Wang, N. (1996). Resistance of Concrete Railroad Ties to Impact Loading. Ph.D. thesis, University of British Columbia, Vancouver, BC.

Conflict of Interest Statement: The authors declare that the research was conducted in the absence of any commercial or financial relationships that could be construed as a potential conflict of interest.

Received: 27 May 2014; accepted: 04 July 2014; published online: 21 July 2014.

Citation: Kaewunruen S, Remennikov AM and Murray $\mathrm{MH}$ (2014) Introducing a new limit states design concept to railway concrete sleepers: an Australian experience. Front. Mater. 1:8. doi: 10.3389/fmats.2014.00008 This article was submitted to Translational Materials Science, a section of the journal Frontiers in Materials. Copyright (c) 2014 Kaewunruen, Remennikov and Murray. This is an open-access article distributed under the terms of the Creative Commons Attribution License (CC BY). The use, distribution or reproduction in other forums is permitted, provided the original author(s) or licensor are credited and that the original publication in this journal is cited, in accordance with accepted academic practice. No use, distribution or reproduction is permitted which does not comply with these terms. 